VAN OOIJEN, J. and R. VoORRIPS (2001): JoinMap 3.0 Software for the calculation of genetic linkage maps, pp. Plant Research International B.V., Wageningen.

VOORRIPS, R. (2001): MapChart version 2.0: Windows software for the graphical presentation of linkage groups and QTLs, pp. Plant Research International, Wageningen, The Netherlands.

Wallace, H. and S. J. TRueman (1995): Dispersal of seeds of Eucalyptus torelliana by the stingless bee, Trigona Carbonaria. Oecologia 104: 12-16.

\title{
Short Note: High Throughput Microsatellite Genotyping in Oak Species
}

\author{
By O. LepAis, V. LÉGER and S. GeRBeR*) \\ UMR BIOGECO, INRA-Université Bordeaux I, 69 route d'Arcachon, 33612 Cestas Cedex, France
}

(Received 21 ${ }^{\text {st }}$ March 2006)

\begin{abstract}
Microsatellites are widely used markers for multiple purposes in oaks. We describe a complete procedure for cheap DNA extraction and fast microsatellites genotyping by multiplex PCR. 10 loci were selected to form two multiplex kits including three loci that show a high differentiation between Quercus robur and Q. petraea. The loci were tested in three oak species and show a high mean genetic diversity of 0.84 . The cumulative exclusion probability for parentage analysis was 0.999977 for single parent and 1.0 for paternity. Finally, the relatively high differentiation coefficient $($ Gst $=0.04)$ will facilitate species assignment based on genotypes in oaks.
\end{abstract}

Key words: microsatellites; multiplex PCR; Quercus; genetic assignment; parentage analysis.

Oaks are common species in a large part of the world and are involved in an increasing number of genetic studies concerning especially population genetic structure and gene flow. New powerful methods for analysing multilocus genetics data allow inference about past demographic events, genetics assignment or detection of selection (CHIKHI and BRUFORD, 2005). We took advantage of technical laboratory progresses to increase availability of multilocus microsatellites data. Combining multiplex PCR and automated capillary sequencer speed up the genotyping compared to silver straining gel or gel plate automated sequencer. In the same time it decreases cost of genotyping and allows to reach high loci number analysis which is needed for high resolution studies in natural populations. In this short note, we present a protocol that allows fast DNA extraction and genotyping for 10 microsatellites in two multiplex PCR.

We used a modified protocol based on CTAB/ dichloromethane (DUMOLIN et al., 1995) allowing DNA extraction in 96 wells plates format. This modification provides high quality DNA extraction from 192 individuals in one day at a low cost compared to commercial kits.

\footnotetext{
*) Communicating author: SopHIE GERBER. Telephone: 0033557122830. Fax: 0033-557122881. Email: gerber@pierroton. inra.fr
}

One centimeter square of leave or three to five buds are cut into small pieces and put in a $1.2 \mathrm{~mL}$ microtube (Qiagen, Cat. No. 19560) with two $2 \mathrm{~mm}$ steel balls, a small amount of insoluble PVP and alumina, $100 \mu \mathrm{L}$ of extraction buffer (CTAB 20 mg.mL ${ }^{-1}$, EDTA (pH 8) $0.02 \mathrm{M}$, Tris $\mathrm{HCl}(\mathrm{pH}$ 8) $0.1 \mathrm{M}, \mathrm{NaCl} 1.4 \mathrm{M}$, soluble PVP $10 \mathrm{mg} . \mathrm{mL}^{-1}$ ). Vegetable tissues and $300 \mu \mathrm{L}$ of extraction buffer are ground in a Retsch-Mill at 30 vibrations per second for $1 \mathrm{~min}$ for each side. The microtubes are incubated at $55^{\circ} \mathrm{C}$ for 1 hour in a vertical position with shaking. After cooling, $300 \mu \mathrm{L}$ of dichloromethane is added and microtubes are shaken. After 20 minutes of centrifugation at $6200 \mathrm{rpm}$ and $4{ }^{\circ} \mathrm{C}$, the upperphase is transferred in new microtubes, $300 \mu \mathrm{L}$ of cold isopropanol is added and after shaking the microtubes are placed at $-20^{\circ} \mathrm{C}$ for 1 hour in a vertical position. After a centrifugation step of 20 minutes at $6200 \mathrm{rpm}$ and $4{ }^{\circ} \mathrm{C}$, the supernatant is removed, $500 \mu \mathrm{L}$ of ethanol is added and microtubes are shaken before centrifugation for 20 minutes at $6200 \mathrm{rpm}$ and $4^{\circ} \mathrm{C}$. Supernatant is then removed and the pellet is dried in a vacuum system concentrator for 15 minutes at $55^{\circ} \mathrm{C}$. Finally the pellet is resuspended in $50 \mu \mathrm{L}$ of pure water. To avoid lost of DNA pellet when removing the upperphase after each centrifugation step, microtubes are kept on ice.

We selected microsatellites loci that are highly differentiated between Quercus robur and Q. petraea (ScoтTISAINTAGNE et al., 2004; P. Goikoetxea, unpublished data). Before multiplexing, primers were checked for primer-primer interaction using the AutoDimer software (VALLONE and BUTLER, 2004). One set, called KIT1, comprises the five following loci QrZAG11, QrZAG39, QrZAG96, QrZAG112 and QpZAG110 and the second one, five others (KIT2): QrZAG5, QrZAG7, QrZAG20, QrZAG65 and QrZAG87 (KAMPFER et al., 1997; STEINKELLNER et al., 1997). On the 10 selected microsatellites, 7 are unlinked (Table 1). Each forward primer was marked with a fluorescent dye (MWG and Applied Biosystems) as shown in Table 1. PCR were carried out in a final volume of $15 \mu \mathrm{L}$ including $5 \mu \mathrm{L}$ of $1 / 50$ to $1 / 200$ diluted DNA, depending on DNA concentration 
Table 1. - Characteristics of the ten microsatellites for a sample of 90 oaks (30 trees by species), Aurignac, France.

\begin{tabular}{|c|c|c|c|c|c|c|c|c|c|c|c|c|c|c|c|c|c|c|c|c|}
\hline \multirow{2}{*}{\multicolumn{2}{|c|}{ Locus }} & \multirow{2}{*}{ Primer Sequence } & \multirow{2}{*}{ LG } & \multirow{2}{*}{$\begin{array}{c}\text { [Primer] } \\
(\mu \mathrm{M})\end{array}$} & \multirow{2}{*}{ Dye } & \multirow{2}{*}{$\begin{array}{l}\text { Allele } \\
\text { Number }\end{array}$} & \multirow{2}{*}{$\begin{array}{l}\text { Size } \\
\text { Range } \\
(\mathrm{pb})\end{array}$} & \multicolumn{3}{|c|}{ Q. robur } & \multicolumn{3}{|c|}{ Q. petraea } & \multicolumn{3}{|c|}{ Q. pubescens } & \multirow{2}{*}{$\mathrm{EP}(\mathrm{sp})$} & \multirow{2}{*}{$E P(p)$} & \multirow{2}{*}{$E P(p p)$} & \multirow{2}{*}{ Gst } \\
\hline & & & & & & & & Ho & $\mathrm{He}$ & Pval & Ho & $\mathrm{He}$ & Pval & Ho & $\mathrm{He}$ & Pval & & & & \\
\hline \multirow[t]{10}{*}{ KIT1 } & QrZAG11 & CCTTGAACTCGAAGGTGTCCTT & 10 & 0.350 & HEX & 16 & $242-286$ & 0.75 & 0.88 & 0.265 & 0.79 & 0.84 & 0.095 & 0.74 & 0.76 & 0.562 & 0.67 & 0.80 & 0.94 & 0.082 \\
\hline & & GTAGGTCAAAACCATTGGTTGACT & & & & & & & & & & & & & & & & & & \\
\hline & QrZAG39 & CACCGCTGGAATTTTAAGGGA & 5 & 0.025 & NED & 17 & 103-139 & 0.86 & 0.85 & 0.728 & 0.67 & 0.92 & 0.003 & 0.83 & 0.93 & 0.309 & 0.71 & 0.83 & 0.95 & 0.015 \\
\hline & & GACCTAAGCCAAAGTGTGGGC & & & & & & & & & & & & & & & & & & \\
\hline & & GGTTGGGAAAAGGAGATCAGA & & & & & & & & & & & & & & & & & & \\
\hline & QrZAG112 & TTCTTGCTTTGGTGCGCG & 12 & 0.040 & FAM & 15 & $72-106$ & 0.74 & 0.66 & 0.931 & 0.47 & 0.61 & 0.005 & 0.81 & 0.85 & 0.216 & 0.36 & 0.55 & 0.77 & 0.042 \\
\hline & & GTGGTCAGAGACTCGGTAAGTATTC & & & & & & & & & & & & & & & & & & \\
\hline & QpZAG110 & GGAGGCTTCCTTCAACCTACT & 8 & 0.300 & FAM & 18 & 193-235 & 0.71 & 0.66 & 0.807 & 0.83 & 0.85 & 0.348 & 0.92 & 0.86 & 0.976 & 0.49 & 0.67 & 0.86 & 0.017 \\
\hline & & GATCTCTTGTGTGCTGTATTT & & & & & & & & & & & & & & & & & & \\
\hline & KIT1 all loci & & & 1.670 & & 85 & & 0.68 & 0.68 & & 0.70 & 0.81 & & 0.82 & 0.86 & & 0.986 & 0.998 & 0.999 & 0.063 \\
\hline \multirow{10}{*}{ KIT2 } & & GTATGTGAGTGTTTGTGGTTTGG & & & & & & & & & & & & & & & & & & \\
\hline & QrZAG7 & CAACTTGGTGTTCGGATCAA & 2 & 0.120 & FAM & 21 & $109-152$ & 0.92 & 0.91 & 0.364 & 0.79 & 0.94 & 0.064 & 0.93 & 0.92 & 0.748 & 0.77 & 0.87 & 0.97 & 0.018 \\
\hline & & GTGCATTTCTTTTATAGCATTCAC & & & & & & & & & & & & & & & & & & \\
\hline & QrZAG20 & CCATTAAAAGAAGCAGTATTTTGT & 1 & 0.150 & HEX & 17 & $155-195$ & 0.78 & 0.78 & 0.472 & 0.90 & 0.88 & 0.807 & 0.83 & 0.90 & 0.509 & 0.56 & 0.72 & 0.89 & 0.010 \\
\hline & & GCAACACTCAGCCTATATCTAGAA & & & & & & & & & & & & & & & & & & \\
\hline & QrZAG65 & CAGTGGTGTCAACTCCTCCCAG & 10 & 0.500 & FAM & 27 & $249-306$ & 0.79 & 0.94 & 0.030 & 0.75 & 0.96 & 0.001 & 0.71 & 0.94 & 0.000 & 0.81 & 0.89 & 0.98 & 0.001 \\
\hline & & GTCAGGTGACCATTCAAACCTAGAA & & & & & & & & & & & & & & & & & & \\
\hline & QrZAG87 & TCCCACCACTTTGGTCTCTCA & 2 & 0.025 & NED & 18 & $101-141$ & 0.81 & 0.85 & 0.231 & 0.73 & 0.88 & 0.053 & 0.78 & 0.81 & 0.506 & 0.64 & 0.78 & 0.93 & 0.051 \\
\hline & & GTTGTCAGCAGTGGGATGGGTA & & & & & & & & & & & & & & & & & & \\
\hline & KIT2 all loci & & & 2.390 & & 105 & & 0.86 & 0.88 & & 0.81 & 0.92 & & 0.82 & 0.90 & & 0.998 & 0.999 & 1.000 & 0.019 \\
\hline
\end{tabular}

Legend - LG: linkage group, Ho: observed heterozygozity, He: expected heterozygozity, EP(sp): single parent exclusion probability, $\mathrm{EP}(\mathrm{p})$ : paternity exclusion probability, $\mathrm{EP}(\mathrm{pp})$ : parent pai exclusion probability, Gst: differentiation coefficient.

and quality. For routine analysis, we advise to test amplification with several DNA dilution to find the one producing a complete amplification in all individuals. PCR reaction buffer contains $1.2 \mathrm{X}$ buffer (Invitrogen), $2 \mathrm{mM} \mathrm{MgCl}_{2}, 0.2 \mathrm{mM}$ dNTPs, 0.025 unit of Taq polymerase (Invitrogen) for one individual and each primer at different concentrations (Table 1) to increase homogeneity of amplification intensity. Even if primer concentrations produced a balanced signal with several DNA extractions series, it can be empirically adjusted to homogenize loci amplification by increasing the primer concentration of weaker loci and at the same time decreasing the primer concentration of stronger loci. The amplification is performed with a MJResearch DNA Engine Tetrad2 (Biorad) thermocycler in ABgene PCR plates (AB-800) covered with adhesive sealing sheets (AB-0558) to avoid evaporation during PCR. The cycling condition consists of a denaturation step of 3 min at $94^{\circ} \mathrm{C}$, following by 30 cycles of $30 \mathrm{~s}$ at $94^{\circ} \mathrm{C}, 30 \mathrm{~s}$ at $50^{\circ} \mathrm{C}$, $90 \mathrm{~s}$ at $65^{\circ} \mathrm{C}$ and a final extension of $15 \mathrm{~min}$ at $65^{\circ} \mathrm{C}$. We found that elongation at $65^{\circ} \mathrm{C}$ reduces stutter phenomena and at the same time increases PCR efficiency during multiplex PCR of microsatellites (HENEGARIU et al., 1997).

After amplification, $8 \mu \mathrm{L}$ of PCR products were mixed with $3 \mu \mathrm{L}$ of bromophenol blue and migrated on $3 \%$ agarose gels for 20 minutes at $100 \mathrm{~V}$ to check for a correct amplification of loci. PCR products were diluted sixfold in pure water and $2 \mu \mathrm{L}$ were combined with $10 \mu \mathrm{L}$ of diluted size standards ET-400Rox (Amersham Bio- sciences). Separation of fragments and alleles detection was carried out on a MegaBACE 100096 capillaries automated sequencer (Amersham Biosciences). Injection parameters were $60 \mathrm{~s}$ at $3 \mathrm{kV}$ and the run was performed during $75 \mathrm{~min}$ at $10 \mathrm{kV}$ and a constant temperature of $45^{\circ} \mathrm{C}$. Data were then scored with the Fragment Profiler v1.2 software (Amersham Biosciences).

The genotyping procedure was tested in several oak species. It gave consistent results for $Q$. robur, $Q$. petraea, Q. pubescens, Q. pyrenaica (European white oaks species) and also for Q. laurina/Q. affinis (Mexican red oaks) and $Q$. resinosa (Mexican white oaks). In $Q$. suber and $Q$. ilex, only few loci were successfully amplified. This shows the transferability limit of microsatellites due to divergence of these species belonging respectively to Cerris and Ilex groups. Loci and multiplex PCR are therefore easily transferable in other white and red oak species.

Both microsatellites multiplex have been tested in 90 oaks of three species: $Q$. robur, $Q$. petraea and $Q$. pubescens from Aurignac (Haute Garonne, France). Allele number, observed and expected heterozygosities and $\mathrm{P}$ value for Hardy-Weinberg exact test (Genepop, RAYMOND and RousseT, 1995) are given in Table 1. Genetic diversity is high with a mean of 0.78 for KIT1 and 0.90 for KIT2. QrZAG65 shows significant heterozygote deficit for all species and some other loci show a significant heterozygote deficit or excess in one of the species.

To test for potential null alleles we genotyped one pedigree (30 offsprings) obtained by controlled crosses of 
two trees (data not shown). All loci followed Mendelian inheritance and none of them, including QrZAG65, showed missing allele. So, we believe that QrZAG65 results indicate that panmixia is not expected in a sample of such a limited size because of the regional sampling and hybridization between species.

The 10 loci could be used for species assignment because they differentiate well between $Q$. robur and $Q$. petraea (Gst $=0.028$ ) but also $Q$. petraea and $Q$. pubescens $(\mathrm{Gst}=0.019$ ) and $Q$. robur and $Q$. pubescens $($ Gst $=0.045)$. Moreover, KIT1 contains QrZAG96, QrZAG112 and QrZAG11, the three highest differentiating microsatellites between $Q$. robur and $Q$. petraea (Scotti-SAintagne et al., 2004). These loci are located close to QTLs involve in leaf morphology that differentiate the two species (SAINTAGNE et al., 2004).

To measure the efficiency of the loci for parentage analysis, we computed exclusion probabilities for single parent $(\mathrm{EP}(\mathrm{sp}))$, paternity $(\mathrm{EP}(\mathrm{p})$ : mother known) and parent pair (EP(pp)) using FaMoz (GERBER et al., 2003). The two sets of microsatellites show high exclusion probabilities which could be slightly overestimated due to partial linkage between some of the loci (Table 1). However, considering such high probabilities, these loci are highly advisable for contemporary gene flow analyses. KIT2 is composed of loci showing high allelic richness and is routinely used for controlled crosses checking in the lab. The DNA extraction procedure and the multiplex PCR described here allow a fast and convenient genotyping for 10 microsatellites in oaks for a wide variety of applications.

\section{Acknowledgements}

We thank PATrick LÉGER and PierRe-Yves Dumolin for the technical support, ERWAN GUICHOUX for helpful comments on protocols, ANTONIO GONZALEZ RODRIGUEZ for Mexican oaks DNA; Johan Fogelqvist, Susanne GustafsSON and MARTIN LASCOUX for invitation at the Evolutionary Functional Genomics Laboratory of Uppsala University under OAKFLOW financial support. This work was founded by the Conseil Régional d'Aquitaine (Convention 20030304002FA), FEDER (Convention $\mathrm{n}^{\circ} 2003227$ ) and the "Bureau des Ressources Génétiques" ("Impact de l'écologie, de l'histoire et du mode de gestion des populations sur la structure de la diversité en forêts fragmentées" project, 2003-2004 call).

\section{Literature}

ChIKHI, L. and M. BRUford (2005): Mammalian population genetics and genomics, pp. 539-584. In: Mammalian Genomics, edited by A. Ruvinsky and J. MARSHALL Graves, CAB International.

Dumolin, S., B. Demesure and R. J. Petit (1995): Inheritance of chloroplast and mitochondrial genomes in pedunculate oak investigated with an efficient PCR method. Theoretical and Applied Genetics 91: 1253-1256.

Gerber, S., P. Chabrier and A. Kremer (2003): FaMoz: a software for parentage analysis using dominant, codominant and uniparentally inherited markers. Molecular Ecology Notes 3: 479-481.

Henegariu, O., N. A. Heerema, S. R. Dlouhy, G. H. Vance and P. H. VoGT (1997): Multiplex PCR: critical parameters and step-by-step protocol. Biotechniques 23: 504-511.

Kampfer, S., C. LeXer, J. GlÖssl and H. Steinkellner (1998): Characterization of $(\mathrm{GA})_{\mathrm{n}}$ microsatellite loci from Quercus robur. Hereditas 129: 183-186.

RAYMOND, M. and F. ROUSSET (1995): GENEPOP version 1.2. population genetics software for exact tests and ecumenicism. Journal of Heredity 86: 248-249.

Saintagne, C., C. Bodénès, T. Barreneche, D. Pot, C. Plomion and A. Kremer (2004): Distribution of genomic regions differentiating oak species assessed by QTL detection. Heredity 92: 30-30.

Scotti-Saintagne, C., S. Mariette, I. Porth, P. G. Goicoechea, T. Barreneche, C. Bodénès, K. Burg and A. KREMER (2004): Genome scanning for interspecific differentiation between two closely related oak species [Quercus robur L. and Q. petraea (Matt.) Liebl.]. Genetics 168: 1615-1626.

Steinkellner, H., S. Fluch, E. TuretscheK, C. Lexer, R. Streiff, A. Kremer, K. Burg and J. GLÖssL (1997): Identification and characterization of $(\mathrm{GA} / \mathrm{CT})_{\mathrm{n}}-$ microsatellite locus from Quercus petraea. Plant Molecular Biology 33: 1093-1096.

VAllone, P. M. and J. M. Butler (2004): Autodimer: a screening tool for primer-dimer and hairpin structures. Biotechniques 37(2): 226-231.

\footnotetext{
Herausgeberin: Bundesforschungsanstalt für Forst- und Holzwirtschaft: Schriftleitung: Institut für Forstgenetik und Forstpflanzenzüchtung, Siekerlandstrasse 2, D-22927 Grosshansdorf — Verlag: J. D. Sauerländer's Verlag, Finkenhofstrasse 21, D-60322 Frankfurt a. M. Anzeigenverwaltung: J. D. Sauerländer's Verlag, Frankfurt am Main. Satz und Druck: ADN Offsetdruck, Battenberg — Printed in Germany.
} 